\title{
HISTOMORPHOLOGICAL SPECTRUM OF BREAST DISEASES
}

\author{
Singh U.R. ${ }^{1}$ \\ Thakur A.N. ${ }^{2}$ \\ Shah S.P. ${ }^{3}$ \\ Mishra A. ${ }^{4}$
}

\section{ABSTRACT:}

All breast lumps are considered to be carcinomas until proved otherwise and are a cause of concern both for the patient and surgeon. The study was undertaken to know the histological spectrum of breast disease at B. P. Koirala Institute of Health Sciences (BPKIHS). BPKIHS is a recently started Medical University in the eastern region of Nepal. No data regarding breast diseases in this region is available as yet. 152 breast tissues sent for histopathology from Jan. 96 - Dec. 98 were studied. Peak incidence of benign lesion was in 21 to 30 years and malignant lesions in 31 to 50 years. No breast lesions were seen in the first decade of life. Cancer was seen in $\mathbf{1 8 . 4 2 \%}$ of cases. Fibroadenoma \& Fibrocystic disease were the commonest benign \& infiltrating duct carcinoma the commonest malignant lesion. Specimens from 10 male breasts were received. Gynaecomastia was the commonest lesion in the males. Infiltrating duct carcinoma was seen in a 70 years male. Some uncommon breast lesions like Syringocystadenoma \& cysticercosis were also seen. In $3.28 \%$ of cases no lesions were seen.

\section{Key Words: Breast, Fibroadenoma, Fibrocystic disease, carcinoma, Gynaecomastia.}

\section{INTRODUCTION:}

Breast lumps are a cause for concern both for the patient and surgeon because of the risk of cancer. Breast cancer is the commonest cancer in females in the developed countries. All breast lumps are usually subjected to microscopic examination. The present study was undertaken to study the histomorphological spectrum of breast disease at BPKIHS. BPKIHS is a recently started Medical

1. Additional Professor, Dept. of Pathology, B.P. Koirala Institute of Health Sciences, Dharan, Nepal.

2. Assistant Professor, Dept. of Pathology, B.P. Koirala Institute of Health Sciences, Dharan, Nepal.

3. Assistant Professor, Dept. of Pathology, B.P. Koirala Institute of Health Sciences, Dharan, Nepal.

4. Senior Professor, Dept. of Pathology, B.P. Koirala Institute of Health Sciences, Dharan, Nepal.

Address for correspondence : $\quad$ Dr. Usha Rani Singh, Reader, Department of Pathology

University College of Medical Sciences \& GuruTegh Bahadur Hospital

Shahdara, Delhi 110095, India.

Fax: 2290495, Email: dbmi@ucms.ernet.in

JNMA, October-December, 2000, 39 
University, which caters to the eastern region of Nepal. No data regarding breast diseases in this region is available as yet.

\section{MATERIAL \& METHODS:}

A retrospective analysis of breast tissue submitted for histopathology from $1^{\text {st }}$ Jan. 96 to $31^{\text {st }}$ Dec. 98 was done. The age, sex, clinical and histomorphological features as recorded in the histopathological files of BPKIHS were studied.

\section{OBSERVATIONS:}

A total of 152 breast tissues were examined in the three years from Jan. 96 to Dec. 98, which formed $2.3 \%$ of the total specimen received for histopathology. The number of breast specimens received for histopathological examination almost doubled in 1998 (Table 1). The number of benign, normal $\&$ inadequate biopsies remained almost similar.

Table 1

Showing the distribution of Breast lesions in the 3 years

\begin{tabular}{|c|c|c|c|c|c|c|}
\hline \multirow{2}{*}{$\begin{array}{c}\text { Year } \\
\text { Breast lesions }\end{array}$} & \multicolumn{2}{|c|}{1996} & \multicolumn{2}{|r|}{1997} & \multicolumn{2}{|c|}{1998} \\
\hline & No & $(\%)$ & No & $(\%)$ & No & $(\%)$ \\
\hline Benign & 32 & $(82.05)$ & 29 & $(70.73)$ & 56 & $(77.78)$ \\
\hline Cancer & 5 & (12.82) & 10 & $(24.39)$ & 13 & (18.06) \\
\hline Normal & 5 & (12.82) & 10 & $(24.39)$ & 13 & $(18.06)$ \\
\hline $\begin{array}{l}\text { Inadequate } \\
\text { Total }\end{array}$ & $\begin{array}{l}0 \\
39\end{array}$ & (0) & $\begin{array}{l}1 \\
41\end{array}$ & $(2.46)$ & $\begin{array}{l}1 \\
72\end{array}$ & (1.39) \\
\hline
\end{tabular}

Specimens from 10 male breasts were received. There were 7 gynaecomastia, one each of fibroadenoma, fibrocystic disease $\&$ breast carcinoma. The age distribution is shown in Table 2. The patient with

$$
\text { Table } 2
$$

Showing the lesions seen in the male breast with age distribution

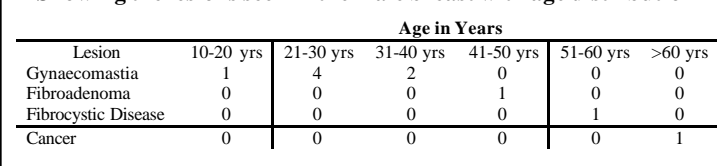

fibrocystic disease also showed atypical ductal hyperplasia. A repeat biopsy done in January 99 showed In-Situ (encysted) papillary carcinoma.
The age of the patients varied from 14-82 years.

Table 3 shows the age distribution of patients with

Table 3

Showing age distribution of benign $\&$ malignant breast lesions.

\begin{tabular}{cc|ccc|cc|c|} 
Breast & \multicolumn{7}{|c|}{ Age in years } \\
\cline { 2 - 8 } lesion & $11-20$ & $21-30$ & $31-40$ & $41-50$ & $51-60$ & $>60$ & Total \\
Benign & 29 & 43 & 31 & 16 & 2 & 1 & 122 \\
Cancer & 0 & 1 & 11 & 10 & 2 & 4 & 28 \\
\hline Total & 29 & 45 & 43 & 26 & 4 & 5 & $150^{*}$
\end{tabular}

* 2 biopsies were inadequate.

benign versus malignant breast lesions. Table 4

Table 4

Showing age distribution of benign breast disease in women

\begin{tabular}{|c|c|c|c|c|c|c|c|}
\hline & \multicolumn{7}{|c|}{ Age in years } \\
\hline $\begin{array}{l}\text { Lesion } \\
\text { Fibroadenoma }\end{array}$ & $\begin{array}{c}11-20 \\
21\end{array}$ & $\begin{array}{c}21-30 \\
11\end{array}$ & $\begin{array}{c}31-40 \\
9\end{array}$ & $\begin{array}{c}41-50 \\
1\end{array}$ & $\begin{array}{c}51-60 \\
0 \\
\end{array}$ & $\begin{array}{c}>60 \\
0 \\
\end{array}$ & $\begin{array}{c}\text { Total } \\
42\end{array}$ \\
\hline $\begin{array}{l}\text { Fibrocystic } \\
\text { Disease }\end{array}$ & 4 & 15 & 10 & 3 & 0 & 0 & 32 \\
\hline Duct Ectasia & 0 & 2 & 5 & 3 & 0 & 0 & 10 \\
\hline $\begin{array}{l}\text { Chronic } \\
\text { Mastitis }\end{array}$ & 0 & 2 & 1 & 1 & 0 & 0 & 4 \\
\hline Adenoma & 1 & 2 & 1 & 0 & 0 & 0 & 4 \\
\hline Abscess & 0 & 2 & 0 & 1 & 0 & 0 & 3 \\
\hline Misc. & 1 & 4 & 2 & 5 & 1 & 0 & 13 \\
\hline Normal & 1 & 1 & 1 & 1 & 0 & 1 & 5 \\
\hline
\end{tabular}

shows the age distribution of patients with benign $\&$ Table 5 the age distribution of patients with

Table 5

Showing age distribution of malignant breast lesions in women

\begin{tabular}{l|c|c|ccccc|}
\multicolumn{1}{c|}{ Lesion } & $11-20$ & $21-30$ & $31-40$ & $41-50$ & $51-60$ & $>60$ & Total \\
\hline Ductal & 0 & 1 & 10 & 8 & 2 & 1 & 22 \\
Lobular & 0 & 0 & 0 & 1 & 0 & 0 & 1 \\
Medullary & 0 & 0 & 0 & 1 & 0 & 1 & 2 \\
\hline Stromal & 0 & 0 & 0 & 0 & 0 & 1 & 1 \\
\hline Phyllodes & 0 & 0 & 1 & 0 & 0 & 0 & 1
\end{tabular}

malignant breast lesions seen in 3 years.

In the Miscellaneous category there were 13 cases. Three cases of mammary fistulae \& two cases of breast ulcers. One patient had bilateral ulcer \& in the other patient with ulcer Pagets disease was considered Clinically. There were two cases of Cysticercus and sweat gland tumour. One each of Atypical ductal hyperplasia, Intraductal Papilloma, Sclerosing adenosis \& Blunt duct adenosis.

In malignant breast lesions there were 23 cases of Infiltrating duct carcinoma, 2 of medullary carci 
noma and one of Lobular carcinoma, stromal sarcoma \& phyllodes tumour.

\section{DISCUSSION:}

The number of breast specimens received remained almost constant $2.41 \%, 1.78 \%$ \& $2.66 \%$ in the years $96,97 \& 98$. The average number of specimens received $(2.3 \%)$ is less than that seen at Calcutta. ${ }^{1}$ Fibroadenoma (28.28\%) followed by fibrocystic disease $(21.71 \%)$ formed the majority of breast lesions sent for histopathology, which is similar to that seen by Yadav et al from Nepal \& Khanna et al $^{3}$ from Banaras-India. The real incidence of fibrocystic disease is difficult to estimate $\&$ diagnosis depends a great deal on individual clinician or pathologist acumen. Cancer was seen in $18.42 \%$ of our cases.

The percentage of carcinoma appears to be slightly higher than that in the west $(10 \%)^{4} \&$ closer to Africa $^{5}(21 \%)$. The benign to malignant ratio was $3: 1$ in the Calcutta ${ }^{1}$ study \& 4:1 in our study. At calcutta the $\%$ of malignancy was higher $(24.44 \%)$ as compared to our study.

Benign lesions were common in the $2^{\text {nd }}$ to $4^{\text {th }} \mathrm{dec}$ ade and malignant lesion in $4^{\text {th }} \& 5^{\text {th }}$ decade, which is similar to that seen in other parts of Nepal. ${ }^{2}$ The peak incidence of benign lump was found in 21 to 30 years age group \& peak incidence of malignant lumps 31 to 50 years which is younger compared to the Western observation. No breast tumours were seen in the first decade of life. The youngest patient was 14 years, similar to that seen in other parts of Nepal. ${ }^{2}$ The rarity of breast disease in the first decade of life is also reported by others.

Lesions of the male breast were seen in 10 cases. In the 10 years study of breast diseases by Oluwule et al in Nigeria $3.9 \%$ of the patients were males. In our study $6.58 \%$ of the patients were male. In
India $^{1} 1.55 \%$ of the patients were males. Gynaecomastia was the commonest breast lesion in the males. The majority of the patients were in the 21-30 years age group. Gynaecomastia formed $4.6 \%$ of the breast lumps which, is higher than that seen in India $(1.4 \%)^{1} \&$ Nigeria $(2.7 \%)^{9}$. The sixty years old male with fibrocystic disease developed an in-situ papillary carcinoma on follow up after 32 months in January 99. Papillary carcinomas are common in Nigeria. ${ }^{9}$ Breast carcinomas occur at an older age in men than females. ${ }^{10}$ In the present study there was only one seventy years old male with cancer breast. The male to female ratio for carcinomas breast was 1:27. Scheiko ${ }^{11}$ found male breast carcinomas comprised $0.8 \%$ of cases of breast carcinomas in Denmark \& the average age at the time of diagnosis to the 65.2 years. In our study male breast carcinomas comprised $3.5 \%$ of cases.

Uncommon tumour like Syringocystadenoma papilleferum was also seen. There are only 2 case reports of this tumour in the world literature. ${ }^{12,13}$ Sweat gland tumours can be seen in the breast, as breast is a modified sweat gland. The other sweat gland tumour seen was a sebaceous cyst.

The commonest age group for malignant breast lesion was 31 to 50 years similar to Yadav et al, Shaikh ${ }^{14} \&$ Maguti. ${ }^{15}$ Infiltrating duct carcinoma was the commonest malignancy seen in the breast $(81.48 \%)$, which is similar to that reported by Khanna $^{3} \&$ Yadav. $^{2}$ There was a single case each of infiltrating lobular carcinoma, stromal sarcoma $\&$ malignant phyllodes tumour. There were two cases of medullary carcinoma.

\section{CONCLUSIONS:}

Breast tissue formed $2.3 \%$ of the total specimen received for histopathology. Majority of the breast 
lumps are benign either fibroadenomas or fibrocystic disease. Benign lesions were common in $2^{\text {nd }}$ to $4^{\text {th }}$ decade and malignancy in $4^{\text {h }} \& 5^{\text {h }}$ decade. Male breast disease though not as common as in the female presents a similar spectrum. Uncommon lesions like Syringocystadenoma papilleferum \& cysticercosis may also be seen in the breast.

\section{REFERENCE:}

1. Chaudhuri M, San S, Sengupta J. Breast lumps; A study of 10 years. J Indian Med Assoc. 1995; 93 (12): 455-7.

2. SS, Kidwai M, Biswas NC. Pattern of diseases in Breast lump. J N Med. Asso. 195-200.

3. Khanna R, Khanna S, Chatuvedi S, Arya NC. Spectrum of breast diseases in young females: A retrospective study of 1315 patients. Indian J Pathol Microbiol. 1998; 41(4): 397-401.

4. Ellis $\mathrm{H}$ and Cox P J: Breast problems in 1,000 consecutive referrals to surgical out-patients. Postgrad. Med. J. 1984, 60. 653.

5. Oluwule Sf, Fadirm OA, Odesammi WO. Diseases of the breast in Nigeria. Br J Surg 1987; 74(7): 582-5.

6. Stone AM, Shenken IR and McCXarthy KL: Adolescent breast masses. Am J Surg 1977; 134:275-77.

7. Seltzer MH and Skiles MS. Disease of the breast in young women. Surg Gyn Obsted. 1980; 150:360-62.
8. Fergusson $\mathrm{CM}$ and Powell RW: Breast masses in young women. Arch Surg 1981; 24:1338-41.

9. Aghadiuno PU. Cancer of the male breast: analysis of 43 cases in Ibadan, Nigeria. Afr J Med Sci 1987; 16(1): 15-26.

10. Spatz MW. Breast cancer in men. Am Fam Physiciam 1988; 38(1): 187-9.

11. Scheiko O. Male breast cancer. Acta Pathol Microbiol Scand 1975; Suppl 251: 3-35.

12. Nowak M, Pathan A, Fatteh S, Fatteh S, Lopez J. Syringocystadenoma papilliferum of male breast. Am J dermatopathol 1998; 20(4): 422-4.

13. Subramony C. Bilateral breast tumour resembling syringocystadenoma papilliferum. Am J Clin Pathol 1987; 87(5): 657-9.

14. Shaikh Sikandar Ali, Burdi Gluam Mohammad, Shaikh Dher Mohammad. Cancer breast experience. In P. J. of Surgery 1994; 10(3): 88-92.

15. Muguti GI. Experience with breast cancer in Zimbabwe. J. R. Coll surg Edinb. 1993; 38: 75-78. 